\title{
Implementation of Fairness Theory in Minimum Wages Policy for Small and Medium Enterprise in Indonesia
}

\author{
${ }^{1}$ Sugeng Prayitno ${ }^{2}$ Irma Rachmawati Ma'ruf, ${ }^{3}$ Budi Drajat Budiman \\ 1,2 Doctor of Law Program, Pasundan University, Indonesia \\ ${ }^{3}$ Magister Notary Program, Pasundan University, Indonesia \\ Email: sugengprayitno310@yahoo.com
}

\begin{abstract}
Wage Minimum always gives disparity in political power and lawmaker since it is tough to describe how to determine individual wages. For this reason, the wage minimum is a dilemma for workers and employers. Fairness conception for wage minimum is a solution to this problem. The fairness conception will guide the wage minimum to the supreme law. Although there are so many regulations concerning wage minimum, there are still many problems that arise, including break the law of wage minimum. The rules must consider the balance of interest between workers and employers to reduce disobedience of minimum wage.
\end{abstract}

Keywords: Fairness Theory, Minimum Wage, Disparity.

\section{A. INTRODUCTION}

Minimum wages are one source of income for workers protected by law. Wages are rights arising from work agreements, and the constitution regulates and protects these rights in article 27 paragraph (2) of the 1945 Constitution of the Republic of Indonesia, which stated: "Every citizen has the right to work and a decent living for humanity. From the Article indicates that the State shall ensure that the entire people to live decently. Meanwhile, Indonesia is a country that is very rich in diversity. Such diversity can be found in daily life, including the existence of various ethnicities, languages, cultures, religions, which are influenced by the geographical location of Indonesia, which is an archipelago. Same as other ASEAN member countries such as Malaysia, Philippine that are archipelagos (Ahmad \& Rachmawati, 2016). In archipelago states, there are various levels of education and the existence of different economic capabilities in society; this causes different ways of thinking and perspectives in the community. As an implementation of constitutional rights, Act Number 13 of 2003 on Labour Law and Government Regulation Number 78 of 2015 concerning Wages regulate wages nationally. Although these Labour Law have been forced for many years ago, this regulation has not yet created harmonious and conducive Industrial Relations in Indonesia (Yetniwati, 2017). Especially when associated with differences that occur in the archipelago state. Different culture makes different incomes to create different levels of fulfillment of basic needs for each community. 
Basic needs would meet the wages if they received the wage to buy real expenses of each individual, including the basic needs of their family. One impact that arises every year is the demonstration conducted by workers/laborers in fighting for their rights to get wages, as a means to meet the necessities of life for workers/laborers and their families. Workers toward their trade unions always demand decent wages, abolish the politics of cheap wages, abolish contract labor systems, outsourcing labor systems, invest in remarkable, and increase the number of components of decent living (KHL) in almost every year (Yetnitawati, 2017).

From the description above, lawmakers need to acknowledge the basic need in advance. Wages are labor rights as a result of the existence of a working relationship between the worker / laborer and the employer. In wages there is a general principle that applies the principle No Work No Pay, which means that workers / laborers will not be paid if they do not do work. But this principle does not apply absolutely in the area of wages, there are exceptions in its implementation, among others, when workers / laborers are sick, on leave, carrying out state duties and others.

According to the theory of justice, John Rawls said: "Social and economic inequality must be regulated in such a way that it can be expected to benefit everyone (Prasetyo, 2006). There must be a balance of the interests of workers and employers contained in the legislation. The worker's interests are fulfilled the needs of his life and that of his family appropriately. At the same time, the benefits of entrepreneurs are the continuity of the business of the company to continue. Social justice should be regulated in the legislation in force, or in other words the positive law must pay attention to justice. After John Rwal's theory, the concept of justice arose which introduced the "Fairness living wage". This concept stems from theoretical concepts namely absolute fairness - that is, the conception of justice which would remedy the adverse effects of employers' superior bargaining power on the labor market. Fairness Living Wage (Absolute Justice), will determine the substantive outcome. The implementation of this concept is that the Government will require employers to pay each worker a minimum wage (Harris, 2006).

Although there has been a lot on procedures for establishing and implementing the minimum wage, but it still happened every year the problems related on the minimum wage. The process of determining the minimum encountered many obstacles, even sometimes there are also indications of breach the law of the stages and mechanism of its determination. Not only stop there, after the Minimum District of Province was determined by the Governor. The infringement that often occurs is that there are still companies/employers who do not want to pay workers/labourers" wages in accordance with the minimum wage ruled by the Governor for various reasons. One of the reasons that is often used by employers is that companies experience setbacks and the minimum wage is too high, so employers are unable to pay wages as determined by the government. 
Various forms of breach of the process of determining and implementing minimum wage can actually be avoided and minimized if all relevant parties want to hold and implement the existing legislation consistently, besides that no less important is the active role of the government, because the government is not only functioning as a legislator, but also functions as a supervisor in the implementation and enforcement of the current Labour Law. The problem is the minimum wage is not just an issue from one factory to another factory, but now it has become a public issue that deserves to be used as study material. The minimum wage dilemma that does not receive attention will result in disharmony Industrial Relations in Indonesia. This also results in not achieving the goals of employment development as well as national development goals. Based on the background of the problem, several problems will be formulated in this paper as follows: (1) How is the concept of wage regulation in Indonesia's positive law viewed from the principle of justice? (2) How are the principles of fair pay in applying the practice in the Cimahi City of Indonesia?

\section{B. METHOD}

The research specification in this paper is descriptive-analysis, descriptive research namely: research is intended to provide research data as thoroughly as possible about humans, circumstances, or other symptoms, whose purpose is to reinforce hypotheses, in order to help in strengthening old theories or discover new theories. Analysis is the elaboration of a subject on the various parts and a review of the part itself and the relationship between the parts to obtain an appropriate understanding and understanding of the overall meaning [2] (). So that the research conducted by the author aims to obtain a clear picture of the Labour Law, in this case concerning the determination and implementation of Regency/City Minimum Wages (MSE), especially in the City of Cimahi.

The method of approach used in this study is normative juridical, which is a research that deductively starts an analysis of the articles in the legislation governing the above problems. Juridical legal research means research that refers to existing literature studies or secondary data used. Whereas normative means legal research that aims to obtain normative knowledge about the relationship between one rule and other regulations and its application in practice.

In analyzing the data carried out by the Juridical-Qualitative method, where the data obtained emphasizes the normative review of the object of research and existing regulations as positive law:

1. That the rules of law are not contradictory to one another.

2. That more specific rules override more general rules.

3. Legal certainty, means that the existing laws and regulations must be obeyed and implemented by the entire community including the government. 


\section{RESULTS}

\section{History of Labor Law in Indonesia}

History of labour law in Indonesia was divided into three phases, namely the pre-independence phase, the phase after independence, the phase after the reform, it is to catch a glimpse of the development of Labour Law in Indonesia.

\section{a. The Pre-Independence Phase}

The world of labour is still coloured by slavery and forced labour, both by the nobles and by the colonizers, in this case the Dutch and Japanese occupation. In 1813 Thomas Stamford Raffles had proclaimed the abolition of compulsory labour, but did not have time to do the abolition, because it ran out. In 1903 there was the result of an investigation which stated that the fate of the workers was very sad because of labour blackmail, labour abuse, supervision in favour of the employer, abuse of court power and so on. So in the period before independence the fate of the workers/labourers was really very alarming and could be said to be at the lowest point, but that does not mean at this time there was no struggle to fight for the workers. The struggle in labour law at this time is often referred to as Panca Krida which contains: freeing Indonesian people from slavery and servitude, freeing the Indonesian population from forced labour, freeing the Indonesian population from punale sanctions (punale sanctions are regulations made by the Netherlands to bind workers so as not to fleeing after entering into an employment contract), freeing workers from the fear of losing their jobs arbitrarily, and giving workers a balanced legal position (including a decent economic position).

\section{b. The Phase After Independence}

In the post-independence phase of labour in Indonesia experienced a slight change, at this phase marked by the absence of slavery and forced labour as happened before independence. It lasted until the end of the old order period and replaced with the new order period. During the new order of labour in Indonesia began to be noticed by the government where the new order was marked by the birth of several labour laws, especially those related to wage problems for workers, such as Government Regulation No. 8 of 1981 concerning Wage Protection, but concerning Labour in general, it is still based on the third book Civil Code, especially Article 1601 to Article 1617.

\section{c. Phase after the Reformation}

In the post-reformation phase, changes occur marked by the birth of Minister of Manpower Regulation Number 1 of 1999 concerning Minimum Wages. The peak of general changes in labour is the enactment and enactment of Law Number 13 of 2003 concerning Labour as a positive law, which means that Civil Code Book III Article 1601 - Article 1617 no longer applies in the world of Manpower, this is based on the principle of lex posteriori derogat legi priori which means if there are new rules and old rules governing the same thing, then what will apply is the new regulation. 


\section{General Definition in Labor Law}

One of the rights for citizens is to get prosperity, this has been formulated in the basis of our country, especially in the fifth precept, Social Justice for All Indonesians, one of which is to get a decent living, which is guaranteed in the constitution we are the 1945 Constitution Article 27 paragraph (2) which states that: "Every citizen has the right to work and an adequate life for humanity", this proves that everyone has the right to live properly without exception, including workers / labourers as mentioned in the background above. With various kinds of laws and regulations governing the rights and obligations of every citizen, especially in this case concerning Labour which includes wages, we can draw a conclusion that Indonesia is actually a rule of law. As what was said Ali, in his book Revealing the Veil of Law, the purpose of law can be seen from three points of view, namely:

1. From the perspective of positive - normative or juridical - dogmatic legal science, where the purpose of law is emphasized in terms of legal certainty.

2. From the perspective of legal philosophy, where the purpose of law is emphasized in terms of justice.

3. From the standpoint of legal sociology, the purpose of law is emphasized in terms of its usefulness.

Labour Law used to be called Labour Law Molenaar provides a definition of Labour Law is part of the applicable law that basically regulates the relationship between workers and employers, between workers and labourers and between workers and authorities Molenaar Understanding Labour Law. Levenbach formulated Labour Law as something that includes laws relating to employment relations, where the work is carried out under the leadership and with a livelihood condition directly related to the employment relationship. While Soepomo provides a definition of Labour Law is a set of regulations, both written and not related to events where a person works for someone else by receiving wages. The term manpower itself has been clearly defined in Law Number 13 of 2003 concerning Manpower, Article 1 point (1) which states that employment is "all matters relating to labour before, during and after work".

\section{Kinds of Wages}

\section{a. Wages based on type}

Wages by type can be divided into: basic wages, fixed benefits, and nonpermanent benefits. Basic wages and fixed benefits are components of wages, the calculation of which is not affected by anything, whether attendance, overtime or other factors. While non-permanent benefits are a component of wages, the calculation of which is influenced by attendance and other factors, including work performance and company capability.

\section{b. Wages Based on Payment Time}

Wages based on the time the payment is divided into: 
1) Monthly wages are wages paid by employers to workers / laborers every month, usually at the end of the current month or the beginning of the following month, so wages are paid once a month.

2) Weekly wages, namely wages paid by employers to workers / laborers every week, can be once a week or every two weeks, so it depends on the agreement of the two parties.

\section{c. Wages by Region}

Wages by area are divided into:

1) Provincial Minimum Wage (UMP), which is the minimum wage that applies to all Regencies / Cities in one Province.

2) City Minimum Wage (UMK) is the minimum wage that applies in the Regency / City area.

\section{d. Wages by Business Sector or Type of Business}

Wages based on the business sector or type of business can be divided into:

Provincial Sectoral Minimum Wage (UMSP) is the minimum wage that applies sectorally in all Regencies / Cities in one Province. City Sectoral Minimum Wage (UMSK) is the minimum wage that applies sectorally in the Regency / City area.

\section{DISCUSSION}

1. The concept of wage regulation in Indonesia's positive law viewed from the principle of justice.

The right to wages is born after an employment relationship and ends when the employment relationship ends. It means that the rights and obligations come after the employment agreement, and the employment agreement will create a work relationship. The agreement was born after the agreement between the worker and the employer. After the agreement is agreed, the parties must be bound by the agreement as the principle of the agreement known as pacta sunt servanda. This implies that a contract that was not made illegally and did not originate from fraud must be fully followed. The employment relationship will end after the expiry of the validity period or stipulated by law, the rights and obligations will end after the employment relationship ends.

Wages consist of several components which must be clearly specified. Components of wages consist of basic wages, fixed allowances and non-permanent benefits. Basic wages must refer to the human needs of life. The wage component will determine the calculation of rights or other wages such as overtime pay, severance pay, insurance premiums. The basic wage is a reward for the worker's services, and the largest part of the wage component is sure to be enjoyed by all workers routinely as long as the employment relationship exists. Thus, the basic wage must be reasonable to meet the needs of a decent worker's life. Benefits are 
for: a. complete basic wages; b. as a work stimulus to be more productive; $c$. as a social function, which is to value the services of workers as human beings when they are faced with unfavorable conditions. Required benefits should include: medical benefits and flexible work benefits for contract workers or outsourcing.

Based on Presidential Decree No. 107 of 2004 concerning Wage Councils, the institution authorized to recommend the UMK value is the Wage Council. The Wage Board is divided and exists at each level, starting from the national level to the Regency/City level. The National Wage Board, hereinafter referred to as Depenas for the national level, Provincial Wage Board, hereinafter referred to as Depeprov for the provincial level, and Regency / City Wage Board, hereinafter referred to as Depekab/Depeko for the Regency / City level. The institution has authority based on Presidential Decree No. 107 of 2004 concerning Wage Councils. The Presidential Decree has explained about how a person can be appointed as a Wage Board, who can be appointed as a Wage Board (including the conditions to become a Wage Board), how to appoint and dismiss, and what are the duties and authority of the Wage Council. With the issuance of KEPPRES Number 107 Year 2004 Concerning Wage Councils, it is expected to minimize the problems that are often faced, especially regarding technical arrangements including regarding procedures for formation, composition, membership requirements, procedures for appointment, termination of membership, and duties and work procedures of the wage council, as mandated by Article 98 paragraph (4) of Law Number 13 of 2003 concerning Labour. If observed, there are several problems that are commonly faced by the Wage Board, including:

a. The lack of clarity on the status of the Wages Board, especially related to the technical arrangement of the position, the requirements of prospective members and the procedure for appointment / dismissal of Wages Council members.

b. The absence of detailed instructions on the procedure for setting minimum wages, including the legal basis for indicators of several aspects of the consideration of setting minimum wages, and access to data and information to the relevant agencies and parties.

c. The professionalism and neutrality of the members of the Wage Board cannot be measured, because there are no clear parameters that can be used to see the work of the Wage Board.

From the explanation above, a conclusion can be drawn that the Wage Board is only a giver of advice or recommendations, however if the advice given is not representative it will have an adverse effect, because there will be parties who feel disadvantaged. In the implementation of any advice and recommendations given by the wage council, the authority to determine the UMK for each regency / city rests with the Governor (Article 89 paragraph (3) of Law No. 13 of 2003 concerning Manpower), which means the Governor holds the consequences of taking 
responsibility for the consequences stipulation of UMK value for a regency / city area

\section{e. Decent Living Needs Survey (KHL) Process}

Related to this problem, before the MSE was determined by the Governor, especially in the City of Cimahi and generally in West Java, the establishment of the UMK was first done by conducting a survey by the City Wage Council (Depeko). According to the Minister of Manpower Regulation No. 13 of 2013 concerning the Components and Implementation of the Stages of Achieving Living Needs, it is stated that the survey is carried out by the City Wages Board (Depeko) periodically and the results are reported to the Governor periodically as well, whereas according to the City Regulation of Cimahi No. 6 of 2010 concerning Manpower Implementation in The City of Cimahi stated that the survey on Decent Living Needs, hereinafter referred to as KHL, was conducted 4 (four) times a year in order to determine the KHL value that could be accounted for. City Wages (Depeko) of Cimahi City, namely in October 2012, on the grounds that the City Wages Board (Depeko) knew and accepted changes in the number of KHL components regulated in Permenaker No. 13/2013 in September 2012 while the Permenaker itself was on July 102012 was ratified and put into effect, which in principle a statutory regulation has been in force since it was passed and it was assumed that all parties knew it. The fact that the government apparatus in this case the Cimahi City Wage Council (Depeko), which also contains elements of the government, gives such reason as a justification to legalize the results of the KHL survey which in fact has violated and is not in accordance with those mandated by statutory regulations a invitation specifically about Manpower.

\section{Determination and Implementation of City Minimum Wage in the City of Cimahi in 2013 as the implementation of fairness theory}

Indonesia as a state of law has a basic norm in the form of the 1945 Constitution which is the state constitution. In this constitution all rights and obligations have been regulated, both the rights and obligations of citizens as well as the rights and obligations of the government. In the 1945 Constitution Chapter XA regulates Human Rights, one of which also regulates the right to live properly. It is stated in Article 28D paragraph (2) that "Every person has the right to work and to receive fair and appropriate compensation and treatment in an employment relationship, from the statement of the Article it is clear that everyone has the right to receive compensation for his work properly, this is in line with the statement of Article 27 paragraph (2) which states "Every citizen has the right to work and a decent living for humanity." From these two Articles, it can be drawn that the right to live properly every citizen has been guaranteed by the constitution whose implementation is the obligation of the State, especially the government, it is 
expressly stated in the 1945 Constitution Article 28I paragraph (4) that the Protection, promotion, enforcement and fulfillment of rights Human rights are the responsibility of the State, especially the government. If it is related to the establishment and implementation of MSEs in Cimahi City, where in its establishment it turns out that the Cimahi City Government does not take an active role in determining MSEs, but leaves it to the workers and employers. While it is clearly mandated by the constitution that the fulfillment of human rights is the responsibility of the State, especially the government, including wages. The fact is the existing laws and regulations, in this case the Minister of Manpower Regulation No. 13 of 2012 concerning the Components and Implementation of the Stages of Achieving Life Needs is contrary to Law No. 13 of 2003 concerning Labour and the Constitution of our country namely the 1945 Constitution, coupled with the attitude of the government that does not want pro-active in the context of fulfilling the mandate of the constitution. The City Government of Cimahi as a state apparatus should properly take every action based on the applicable laws and regulations, in this case specifically in the field of Labour. Another fact that occurs is that there are still companies that do not run the new UMK value, and still pay wages below the UMK value set by the Governor.

In an effort to guarantee the implementation of the laws and regulations in the field of manpower is the responsibility of labour inspectors, this has been expressly stated in Article 176 of Law No. 13 of 2003 concerning Manpower, that "Labour inspection is carried out by labour inspectors who have competence and are independent in order to guarantee the implementation of labour laws and regulations". The fact is that supervisory employees do not take any action against companies that commit violations in the form of paying wages below the UMK. In Law No. 13 of 2003 concerning Manpower it has been stated clearly and clearly, that for companies that pay wages below the UMK without going through a suspension process is a criminal offense and threatened with criminal sanctions for a minimum of 1 (one) year, a maximum of 4 (four) years, or a fine of at least 100 million, a maximum of 400 million (Article 90 paragraph (1) Jo Article 185 of Law No. 13 of 2003 concerning Labor). Law enforcement in the field of Manpower in Cimahi City, especially regarding MSEs in Cimahi City in 2013 will be difficult to enforce, if the Cimahi City Government continues to neglect violations committed by several of these companies. The problem is felt even more complicated when there are parties who feel disadvantaged and cannot accept the determination of the value of the Cimahi City UMK in 2013, which in this case is the worker. Workers continue to uphold their opinion that the 2013 UMM Cimahi UMK determination process is invalid, because it does not go through procedures that have been regulated by laws and regulations on Labour.

Human Rights is the responsibility of the State, especially the government, then as Implementation of 1945 regulating wages and decent living is the enactment 
of Law No. 13 of 2003 on Labour in particular Article 88 paragraph (1) and for an explanation, which in that Article it has been clearly stated that what is meant by income (wages) fulfilling a decent livelihood is the income of workers from the results of their work so as to be able to meet the living needs of workers / labourers and their families, including clothing, food, housing, education, health, recreation and old age. The fact is that Permenaker No. 13/2012, which includes components of the necessities of decent living (KHL), states that KHL is counted for single workers, while Law No. 13/2003 states that KHL is not only for workers, but also their families, in this case the wife / husband and children of workers. This is coupled with the statement of Permenaker No. 1 of 1999 in particular Article 14 paragraph (2) which states that the UMK is only intended for workers who have a working period of less than 1 (one) year, while for workers who have 1 (one) year work period and so on, then the wage value is left to the parties, in this case the workers and employers through bipartite negotiations (negotiations conducted by two parties without the other parties involved). In the 1945 Constitution and Law No. 13 of 2003 concerning Labour the function of the government is very clear, namely as an authorized and responsible party in the fulfillment and enforcement of Human Rights, in this case concerning proper wages for workers / labourers. As explained in the previous chapter, the position of workers/labourers is not balanced when dealing with employers. This is coupled with the absence of sanctions, if there are companies that commit violations, one of which is a violation of paying the wages of workers who have more than one year of service only at the value of the applicable MSE.

With the enactment of regional autonomy, the Cimahi City government should be able to take an active role in the protection of workers / labourers through a wage policy as mandated by Law No. 13 of 2003 on Manpower, in this case the MSE that is enforced in Cimahi City, so that the Cimahi City Government is not only be the party that functions as a spectator, but can be the party who takes the policy in determining the value of MSEs in the City of Cimahi that can meet the needs of a decent life such as the mandate of our country's constitution, the 1945 Constitution.

\section{Problems that Occur in the Implementation of MSEs (City Minimum Wages) in Cimahi City and Efforts to overcome them.}

a. Problems with the implementation of MSEs in the City of Cimahi

1) As a result of legal efforts against the West Java Governor's Decree on Minimum Wages in the City / Regency in West Java the implementation of MSEs in the City of Cimahi, the first problem arises when the West Java Governor's Decree on Minimum Wages in the City / Regency in West Java has been ratified, but there are still parties who make legal efforts against the Governor's Decree, because they have not been able to accept the UMK value 
that has been ratified. Specifically in the City of Cimahi, the problem is in the form of several companies that do not want to apply the new UMK value, on the grounds that there are still legal efforts by the workers, by making a lawsuit against the decree to the State Administrative Court (PTUN) Bandung. Even though the law is known as the principle of res judicata provere tate habetur, which means that the decision is considered right before it is proven otherwise, this can be interpreted that the UMK value must be enforced, even though there are legal efforts made by workers to PTUN Bandung.

2) Companies that have objections and do not want to pay the value of MSEs in the City of Cimahi in 2013 Another problem that arose with the increase in the value of MSEs in the City of Cimahi in 2013 was the existence of companies that did not want to pay workers' wages in accordance with the new MSE values. Many reasons were put forward by the company to justify its actions, including: the company reasoned that it was losing / experiencing setbacks, the company was unable because the UMK value was too high, some even used the reason that if the new MSE was enacted, the company would close or the company would do efficiency by means of termination of employment (FLE). Whereas in Kepmenaker No. 231 Regarding the Procedure for Suspending the Implementation of the Minimum Wage, it has been clearly stipulated how the procedures and procedures for the suspension of wages for companies that are unable to carry out the minimum wage.

3) Wage problems for workers / laborers with work periods above 1 (one) year In addition to the problems mentioned above, there are problems that occur every year and there is no solution, namely that there are still many companies that pay workers who have a work period of more than one year only at the specified UMK value. Whereas Permenaker No. 1 of 1999 concerning Minimum Wages has stated clearly and firmly that MSE is only intended for workers / laborers who have a working period of less than 1 (one) year. For workers / laborers with more than 1 (one) year work period the wages are negotiated between the workers / laborers and the employers, the problem that arises is an unbalanced bargaining position between the workers / laborers and the employers.

\section{b. Efforts to overcome the problems of implementing MSE}

In dealing with problems with the implementation of MSEs in the City of Cimahi, more are done by workers / laborers, in this case trade unions / labor unions, compared to what the government has done. The efforts that have been made are:

1) Regarding the problem that there are companies that do not want to impose new MSE values on the grounds that they are still in dispute, a persuasive attempt is made by workers / laborers in this case the trade unions against the 
company by holding a bipartite meeting for deliberation, so that the problem can be completed with the implementation of the new UMK value in the company.

2) Steps taken to overcome the problem, in the form of companies that do not want to apply the new UMK value on the grounds that the company is unable or the company experiences setbacks without going through a mechanism of wage suspension are workers / laborers, in this case the union / labor union invites the company to meet and negotiations, which are expected to have a meeting point between the two parties, if the negotiations do not produce results, then the workers / laborers in this case the union / labor union will make a written report to the Cimahi City Labor Office, in this case supervision field. Ironically from the report, the Cimahi City Labor inspector only issued a memorandum of supervision, and there was no attempt by the government agency to make other efforts so that the problem could be resolved. An example is what happened at PT Karya Putera Pahlawan, which is located at Kihapit Timur Street Number 50 Cimahi. In the event of a violation of the City Minimum Wage (UMK) payment, the union reported the problem to the Cimahi City Manpower Office Supervisor. After receiving the report, the Cimahi City Manpower Office Supervisor conducted an inspection to the company, which was followed up by issuing a Memorandum of Understanding Number: 560/298/Disnakertransos, which contained violations committed by the company. Until the author completed this research, the company still pays the City Minimum Wage (UMK) under the provisions of the 2013 City Cimahi Minimum Wage (UMK), and there has been no further action from the relevant agencies against the company that committed the violation.

3) With regard to the latest problem that has occurred for many years, namely regarding workers / laborers who are paid only at the value of the UMK, even though the worker / laborer has a working period of more than one year. If the worker / laborer fails to negotiate bipartite and complains with the Cimahi City Manpower Office, then the answer obtained is that the problem please be negotiated to both parties and if there is no common ground, please proceed in accordance with applicable laws and regulations, namely through mediation (tripartite meetings between the workers / laborers, employers, and the government, which in this case is the Mediator of the Cimahi City Manpower Office), which will produce recommendations, and if the parties cannot accept these recommendations, they are welcome to bring a lawsuit to Industrial Relations Dispute Court (PPHI). So the Cimahi City government seems to only make efforts to abort obligations in carrying out its duties, while in solving these problems it is more up to the parties (the workers / laborers and the employers), this tends to harm the workers / laborers because of the 
bargaining position between the workers / laborers with the businessman is very unbalanced. So it will be difficult to resolve by negotiation and deliberation to get a win-win solution, if the bargaining position of each party is not balanced.

\section{E. CONCLUSION}

The implementation justice principle in the minimum wage, namely : The right to wages is born after an employment relationship and ends when the employment relationship ends; Wages consist of several components which must be clearly specified; There should be no wage gender and racial discrimination; The government must protect workers' wages; An appreciation for more productive workers; Transparency in wage management; The parties who because of intentional or negligence result in losses to the opposing party are subject to sanctions; Priority right to wages if a businessman goes bankrupt; The implementation of UMK in Cimahi City in 2013, if connected with the mandate of the 1945 Constitution, especially Article 27 paragraph (2), can be concluded that the UMK value is very contradictory and does not reflect what is contained in that Article. This can happen because there is no harmonization and synchronization between the mandate of Article 27 paragraph (2) of the 1945 Constitution, which concerns about a decent living for humanity, with the laws and regulations that become the implementing regulations, namely between Law No. 13 of 2003 on Labour Law. Whereas the still weak supervision of the implementation of MSEs in Cimahi City because the settlement of MSEs violations tends to be left to the parties in this case the workers / labourers with employers through bipartite, mediation and court channels in this case the Industrial Relations Dispute Court (PPHI), while the Law The Manpower Act has mandated that the government must make a policy on wages to protect the interests of workers / labourers and also conduct oversight of the implementation of the Minimum Wage.

\section{REFERENCES}

1. Acs, Z. J., Morck, R., Shaver, J. M., \& Yeung, B. (1997). The internationalization of small and medium-sized enterprises: A policy perspective. Small business economics, 9(1), 7-20.

2. Ahmad, R., \& Rachmawati, I. (2016). Implementation of Protection and Indemnity for Indonesian Ship a Compliance to Common Law System. International Journal of Applied Business and Economic Research, 14(6), 1-19.

3. Agustin, R. (2017). Complete Indonesian Dictionary. Surabaya.

4. Ali, A. (2017). Revealing the Veil of Law. Jakarta: Kencana.

5. Cimahi City Regulation No. 6 of 2010 concerning Manpower Implementation in Cimahi City 
6. Artonang. (2016). Understanding of Labor Law. Retrieved http://artonang.blogspot.com/2016/05/peng understanding-hukum-kenen.html.

7. Bell, L. A. (1999). The impact of minimum wages in Mexico and Colombia. The World Bank.

8. Gan, L., Hernandez, M. A., \& Ma, S. (2016). The higher costs of doing business in China: Minimum wages and firms' export behavior. Journal of International Economics, 100, 81-94.

9. Gibb, A. A. (1993). Key factors in the design of policy support for the small and medium enterprise (SME) development process: an overview. Entrepreneurship $\mathcal{E}$ Regional Development, 5(1), 1-24.

10. Guide to Compilation of Law Writing, Faculty of Law, Pasundan University, Bandung Basic Law of 1945 Code of Civil law Law No. 13 of 2003 concerning Employment.

11. Ling, T. P., Yusof, M. F., Mahmood, N. H. N., \& Soon, T. H. (2014). The implementation of minimum wages in Malaysia. Sains Humanika, 2(2).

12. Minister of Manpower and Transmigration Regulation No. 1 of 1999 concerning Minimum Minimum.

13. Minister of Manpower and Transmigration Regulation No. 13 of 2012 Concerning Components and Stages of Achieving the Need for Decent Living.

14. Ni, J., Wang, G., \& Yao, X. (2011). Impact of minimum wages on employment: evidence from china. Chinese Economy, 44(1), 18-38.

15. Republic of Indonesia Law Concerning Manpower.

16. Sacconi, L. (2011). A Rawlsian view of CSR and the Game Theory of its Implementation (Part II): Fairness and Equilibrium. In Corporate Social Responsibility and Corporate Governance(pp. 194-252). Palgrave Macmillan, London.

17. Soepomo, I. (2003). Introduction to Labor Law. Jakarta: Djambat.

18. Storey, D. J. (2003). Entrepreneurship, small and medium sized enterprises and public policies. In Handbook of entrepreneurship research (pp. 473-511). Springer, Boston, MA.

19. Yetniwati, Y. (2017). Pengaturan Upah Berdasarkan Atas Prinsip Keadilan. Mimbar Hukum-Fakultas Hukum Universitas Gadjah Mada, 29(1), 82-95.

20. Yuridksilaw. (2016). Understanding Labor Law. Retrieved from http://ykamahiksilaw.blogspot.com/2016/04/pengunderstanding-hukumbburuh.html. 